\title{
Developmental Acquisition of Voltage-Dependent Conductances and Sensory Signaling in Hair Cells of the Embryonic Mouse Inner Ear
}

\author{
Gwenaëlle S. G. Géléoc, Jessica R. Risner, and Jeffrey R. Holt \\ Departments of Neuroscience and Otolaryngology, University of Virginia School of Medicine, Charlottesville, Virginia 22932
}

\begin{abstract}
How and when sensory hair cells acquire the remarkable ability to detect and transmit mechanical information carried by sound and head movements has not been illuminated. Previously, we defined the onset of mechanotransduction in embryonic hair cells of mouse vestibular organs to be at approximately embryonic day 16 (E16). Here we examine the functional maturation of hair cells in intact sensory epithelia excised from the inner ears of embryonic mice. Hair cells were studied at stages between E14 and postnatal day 2 using the whole-cell, tight-seal recording technique. We tracked the developmental acquisition of four voltage-dependent conductances. We found a delayed rectifier potassium conductance that appeared as early as E14 and grew in amplitude over the subsequent prenatal week. Interestingly, we also found a low-voltage-activated potassium conductance present at E18, 1 week earlier than reported previously. An inward rectifier conductance appeared at approximately E15 and doubled in size over the next few days. We also noted transient expression of a voltage-gated sodium conductance that peaked between E16 and E18 and then declined to near zero at birth. We propose that hair cells undergo a stereotyped developmental pattern of ion channel acquisition and that the precise pattern may underlie other developmental processes such as synaptogenesis and functional differentiation into type I and type II hair cells. In addition, we find that the developmental acquisition of basolateral conductances shapes the hair cell receptor potential and therefore comprises an important step in the signal cascade from mechanotransduction to neurotransmission.
\end{abstract}

Key words: hair cell; conductance; mechanotransduction; development; utricle; vestibular

\section{Introduction}

Sensory signaling in mechanosensitive hair cells of the mammalian inner ear requires a host of ionic conductances, the significance of which has been underscored recently by the finding that disruption of several classes of ion channel genes, including calcium and potassium channels, causes deafness and balance deficits in humans and mice (Neyroud et al., 1997; Holt and Corey, 1999; Kubisch et al., 1999; Platzer et al., 2000). Despite recent advances in the genetics of inner ear dysfunction, there has been little progress toward understanding the pathophysiology of congenital hearing and balance disorders. Morphological and physiological hair cell development have been well documented over the first postnatal week in mammals (for review, see Eatock and Hurley, 2003), but little is known about functional hair cell development before birth. We recently solved part of the puzzle by demonstrating the concurrent acquisition of hair cell transduction elements and fully functional mechanosensitivity at approximately embryonic day 16 (E16) (Géléoc and Holt, 2003). Ex-

Received July 5, 2004; revised 0ct. 24, 2004; accepted 0ct. 30, 2004.

This work was supported by National Institute on Deafness and Other Communication Disorders Grants DC006183 (G.S.G.G.) and DC05439 (J.R.H.). We thank David Abraham, Jonathan Ashmore, and Eric Stauffer for critical review of a previous version of this manuscript and Holly Eppard for technical support.

Correspondence should be addressed to Dr. Jeffrey R. Holt, Departments of Neuroscience and Otolaryngology, University of Virginia, MR4, Room 5126, Box 801392, Charlottesville, VA 22908-1392. E-mail: jeffholt@virginia.edu. D01:10.1523/JNEUROSCI.2662-04.2004

Copyright $\odot 2004$ Society for Neuroscience $\quad 0270-6474 / 04 / 2411148-12 \$ 15.00 / 0$ panding on that study, we investigated the developmental acquisition of voltage-dependent conductances in embryonic mouse vestibular hair cells and examined their impact on the hair cell receptor potential.

In the vestibular sensory epithelium, hair cells first appear at approximately E12 (Ruben, 1967), and small hair bundles are apparent as early as E14 (Denman-Johnson and Forge, 1999). Biphasic growth in the number of hair cells suggests that a second wave of hair cells is produced at approximately E15 (Mbiene et al., 1984; Denman-Johnson and Forge, 1999). A host of morphological changes ensue. Stereocilia, which comprise the mechanosensitive hair bundle, grow in length at a rate of $\sim 1 \mu \mathrm{m} / \mathrm{d}$ up to $\sim 10 \mu \mathrm{m}$ and establish a staircase array of heights. Concurrently, the kinocilium grows and is eccentrically placed establishing hair bundle polarity and orientation. Bouton synaptic contacts between hair cells and afferent nerve fibers form as early as E15 (Mbiene et al., 1988), which is presumably followed by functional synaptogenesis. Calyceal afferent endings and morphological differentiation into flask-shaped type I cells begin to take shape several days before birth.

Electrophysiological maturation has been documented in neonatal mouse cochlear hair cells (Kros et al., 1998; Marcotti et al., 1999, 2003), neonatal chick vestibular cells (Sokolowski et al., 1993; Masetto et al., 2000), and postnatal mouse vestibular cells (Rüsch et al., 1998). At birth, mouse vestibular hair cells express a conventional delayed rectifier conductance $\left(G_{\mathrm{DR}}\right)$, as well as a fast 
inward rectifier conductance $\left(G_{\mathrm{K} 1}\right)$. At later stages [postnatal day 4 (P4) to P8], Rüsch et al. (1998) found evidence for a type I-specific delayed rectifier potassium conductance, $G_{\mathrm{K}, \mathrm{L}}$, and a hyperpolarization-activated conductance, $G_{\mathrm{h}}$. In this study, we describe the prenatal acquisition of voltage-gated potassium and sodium conductances. We demonstrate that acquisition of $G_{\mathrm{DR}}$ and $G_{\mathrm{K} 1}$ begins at approximately E14-E15 and that $G_{\mathrm{K}, \mathrm{L}}$ expression actually begins a few days before birth. In addition, prenatal hair cells transiently express a tetrodotoxin (TTX)-insensitive sodium conductance that peaks between E16 and E18. As such, we define a distinct physiological timeline for the functional development of vestibular hair cells and demonstrate how each conductance shapes the hair cell receptor potential.

\section{Materials and Methods}

Tissue preparation. Utricles were excised from embryonic (E14-E19) and postnatal (P0-P2) Swiss Webster mice (Hilltop Lab Animals, Scottdale, PA and Taconic Farms, Germantown, NY). Standard procedures were followed to ensure accurate management of the timed pregnant mouse colony: animals were paired on "mate day 0"; females with vaginal plugs the next morning were considered sperm positive and isolated; the day the vaginal plug was observed was considered day 1 of gestation (E1). Date of birth (P0) in this strain was typically at E20. The developmental age of embryos was carefully checked after their isolation by analyzing their overall morphological appearance (Kaufman, 1992; Davidson et al., 2002). The embryo's weight was recorded to produce a developmental chart that was also used to confirm embryonic stages for this strain. Timed pregnant females were anesthetized with $\mathrm{CO}_{2}$, and the embryos were removed by cesarean section. Embryonic and neonatal mice were decapitated. The temporal bone was removed, and the bony labyrinth was opened medially to expose the utricle. When the otolithic membrane was present (after E15), the tissue was bathed in MEM solution (Invitrogen, Carlsbad, CA) containing $0.1 \mathrm{mg} / \mathrm{ml}$ protease XXIV (Sigma, St. Louis, MO) for 15-20 min. The otolithic membrane was removed, the utricle was excised, and the nerve fibers were trimmed close to the epithelium. The tissue was mounted onto a round glass coverslip and held in a flat position by two glass fibers glued to the coverslip.

Scanning electron microscopy. To assess the morphological appearance of hair bundles at various developmental stages, scanning electron microscopy (SEM) was performed. Utricular sensory epithelia were excised from embryonic mice at E15 and E17 as described above. The sensory epithelia were fixed at $4^{\circ} \mathrm{C}$ for 90 min with $2.5 \%$ glutaraldehyde in 100 mu cacodylate buffer with $3 \mathrm{~mm} \mathrm{CaCl}_{2}$, $\mathrm{pH}$ 7.4. Specimens were washed three times in PBS buffer (Invitrogen) and postfixed in $1 \%$ osmium tetroxide dissolved in cacodylate buffer for $30 \mathrm{~min}$. Samples were rinsed three times in PBS before alcohol series dehydration. After critical-point drying in liquid $\mathrm{CO}_{2}$, the specimens were sputter coated with gold-palladium and examined with a Jeol (Peabody, MA) 6400 scanning electron microscope at $25 \mathrm{kV}$.

Solutions. Dissections were performed in standard MEM solution (Invitrogen) supplemented with $10 \mathrm{~mm}$ HEPES, pH 7.4. Electrophysiological recordings were performed in an artificial perilymph solution that contained the following (in $\mathrm{mm}$ ): $144 \mathrm{NaCl}, 5.8 \mathrm{KCl}, 10$ HEPES, 0.7 $\mathrm{NaH}_{2} \mathrm{PO}_{4}, 1.3 \mathrm{CaCl}_{2}, 0.9 \mathrm{MgCl}_{2}$, and $5.6 \mathrm{D}$-glucose, vitamins at 1:50, and amino acids at 1:100 (Invitrogen), pH 7.4 and $320 \mathrm{mOsm} / \mathrm{kg}$. Recording pipettes were filled with an intracellular solution that contained the following (in mM): $135 \mathrm{KCl}, 5$ EGTA-KOH, 5 HEPES, $2.5 \mathrm{~K}_{2} \mathrm{ATP}, 3.5$ $\mathrm{MgCl}_{2}$, and $0.1 \mathrm{CaCl}_{2}, \mathrm{pH} 7.4(290 \mathrm{mOsm} / \mathrm{kg})$. Sodium-free solutions were generated by replacing $144 \mathrm{~mm} \mathrm{NaCl}$ with $144 \mathrm{~mm} \mathrm{~N}$-methyl-Dglucosamine (NMDG)-Cl.

Electrophysiology. Utricular sensory epithelia were placed onto a microscope chamber and viewed with a $63 \times$ water-immersion lens with differential interference contrast (DIC) optics (Axioskope FS; Zeiss, Oberkochen, Germany). Recording pipettes were pulled from borosilicate capillary glass (Garner Glass, Claremont, CA) with resistances that ranged from 2 to $5 \mathrm{M} \Omega$. The apical surface of the epithelium was viewed from above as the recording pipette was advanced. When a cell was chosen for the study, its hair bundle morphology, cell shape, position along the epithelium, and the presence of a partial afferent contact was noted. Positive pressure was maintained as the recording pipette was lowered into the epithelium. When the pipette touched the membrane, positive pressure was released and a tight seal formed on the basolateral membrane of the cell. Recordings were obtained at room temperature $\left(22-24^{\circ} \mathrm{C}\right)$. The cells were held at $-64 \mathrm{mV}$, and data were acquired using the whole-cell tight-seal technique in both voltage-clamp and currentclamp modes using an Axopatch multiclamp 200B amplifier (Axon Instruments, Foster City, CA), filtered at $1 \mathrm{kHz}$ with a low-pass Bessel filter, digitized at $5 \mathrm{kHz}$ with a 12-bit acquisition board, and collected using pClamp 8.0 software (Axon Instruments). Voltage protocols are described for each experiment. Not all protocols were run on every cell.

Analysis. Data analysis was performed using Origin 7.1 (Microcal Software, Northampton, MA). Series resistance $\left(R_{\mathrm{s}}\right)$ and whole-cell capacitance $\left(C_{\mathrm{m}}\right)$ were read from the amplifier after electronic subtraction of capacitive transients. Membrane potentials were corrected offline for series resistance and for liquid junction potential $(-4 \mathrm{mV})$. Results are presented as means $\pm \mathrm{SD}$ unless noted otherwise. $n$ values represent subsets of the total 126 cells examined for which data were available, as specified in Results.

We fitted the instantaneous current $(I)$ as a function of time $(t)$ carried by the outward rectifiers $G_{\mathrm{DR}}$ and $G_{\mathrm{K}, \mathrm{L}}$ with an equation used by Rüsch et al. (1998) to describe the sigmoidal current activation in postnatal utricle cells:

$$
I(t)=I_{\infty}-\frac{\left(I_{\infty}-I_{0}\right)}{\tau_{1}-\tau_{2}}\left(\tau_{1} e^{-t / r_{1}}-\tau_{2} e^{-t / r_{2}}\right)
$$

$I_{\infty}$ is the steady-state current, $I_{0}$ is the current at time 0 , and $\tau_{2}$ and $\tau_{1}$ are time constants that describe the sigmoidal onset and approach to steadystate, respectively.

Activation curves and inactivation curves were fitted where conductance $(G)$ as function of membrane potential $\left(V_{\mathrm{m}}\right)$ was described by a Boltzmann equation of the following form:

$$
G\left(V_{\mathrm{m}}\right)=G_{\min }+\frac{G_{\max }-G_{\min }}{1+\exp \left(\frac{V_{1 / 2}-V_{\mathrm{m}}}{S}\right)}
$$

$G_{\max }$ and $G_{\min }$ are the maximum and minimum conductances, respectively. $V_{1 / 2}$ is the midpoint of the curve at which half of the conductance is activated, and $s$ is the slope of the curve at the midpoint.

Sodium $I-V$ relationships were fitted with an equation used previously to describe sodium currents in rat outer hair cells (Oliver et al., 1997), where $V_{\text {rev }}$ is the sodium reversal potential:

$$
I\left(V_{\mathrm{m}}\right)=\frac{G_{\max }\left(V_{\mathrm{m}}-V_{\text {rev }}\right)}{1+\exp \left(\frac{V_{1 / 2}-V_{\mathrm{m}}}{S}\right)}
$$

\section{Results}

Because tracking the electrophysiological maturation of individual hair cells as a function of embryonic development is not feasible, we opted to study populations of cells at several developmental stages. We suspect that the mean temporal patterns of ion channel acquisition in our populations are representative of the pattern through which individual cells mature. To ensure that we sampled as uniform a population as possible, we selected cells from the central region that had healthy cell bodies (i.e., lacked swelling and Brownian motion) and intact hair bundles of sufficient size that they could be conclusively determined to be members of the first wave of differentiation.

Hair cells appear in two waves, with the first wave appearing in the central region at approximately E12 and the second wave appearing at approximately E15 and expanding to include the peripheral regions (Denman-Johnson and Forge, 1999). Consis- 
tent with that notion, we observed hair bundles of relatively uniform height at $\operatorname{E15}(2.3 \pm 0.4 \mu \mathrm{m} ; n=48)$ throughout the central region (Fig. 1A). By E17, a bimodal distribution of hair bundle heights, charted in Figure $1 C$, suggested that a second population of hair cells had emerged (Fig. $1 B)$. The taller bundles $(6.6 \pm 0.7$ $\mu \mathrm{m} ; n=26)$ presumably reflected the more advanced bundle growth of the older, first wave of hair cells and were found only in the central region. The shorter bundles $(2.6 \pm 0.9 \mu \mathrm{m} ; n=28)$, which were likely the result of the younger, second wave of hair cell differentiation, were found throughout the sensory epithelium (Fig. 1C) but at greater density in the peripheral zone (data not shown). This distinction was also apparent with the DIC optics used to view the intact sensory epithelium in our recording paradigm. When viewed from above, the taller hair bundles of the older cells were easily distinguished by the greater range required to focus through the entire hair bundle from the cuticular plate to the tip of the tallest stereocilium.

Using location and bundle height as a guide, we recorded from 126 cells at stages that ranged from E14 to P1. These 126 cells were selected for analysis because they met the following criteria: the seal resistance was stable over the duration of the recording, and each cell had either an input resistance of $>500 \mathrm{M} \Omega$ or a zerocurrent potential negative to $-30 \mathrm{mV}$. The selection criteria were designed to allow for inclusion of immature cells that had depolarized resting potentials and cells with large conductances active at rest (i.e., low input resistances) but to exclude data from poor quality recordings: unstable seal resistances or both a low input resistance and a depolarized resting potential.

We charted several membrane properties as a function of developmental stage in the absence of stimulation. Figure $2 \mathrm{~A}$ shows that the whole-cell capacitance increased as a function of embryonic age from a mean of $3.3 \pm 1.1 \mathrm{pF}(n=6)$ at E15 to $5.0 \pm 1.3$ $\mathrm{pF}(n=16)$ after birth. The data were fit with a linear regression with a slope of $0.3 \mathrm{pF} / \mathrm{d}$, which closely parallels the increased capacitance expected from an average growth rate of $\sim 1 \mu \mathrm{m} / \mathrm{d}$ (Denman-Johnson and Forge, 1999) for $\sim 50$ stereocilia with diameters of $0.2 \mu \mathrm{m}$. At the same time, the zero-current potential, a good indicator of resting potential, became more negative between $\mathrm{E} 14$ and $\mathrm{E} 19$, ranging between $-36 \pm 11 \mathrm{mV}(n=3)$ and $-60 \pm 12 \mathrm{mV}(n=16)$, respectively (Fig. $2 B)$.

Input resistance $\left(R_{\mathrm{IN}}\right)$, an indicator of cell membrane resistance and the number of channels open at rest, did not vary as a function of age with the exception that, at E18 or older, a significant fraction (28 of 82 ) of the cells had a very low input resistance $(<200 \mathrm{M} \Omega)$. Figure $2 C$ revealed a bimodal distribution of input resistances: the mean $R_{\mathrm{IN}}$ for the 28 low $R_{\mathrm{IN}}$ cells was $55 \pm 41 \mathrm{M} \Omega$, whereas the $R_{\mathrm{IN}}$ for the remaining cells was $1390 \pm 830 \mathrm{M} \Omega(n=$ 98 ). As will be demonstrated in the following sections, the low $R_{\mathrm{IN}}$ was strongly correlated with the acquisition of a low-voltageactivated potassium conductance that was active at the holding potential of $-64 \mathrm{mV}$.

\section{Delayed rectifier conductance}

Figure $3 A$ shows representative families of currents recorded at developmental stages between E14 and E19. The currents were evoked by $100 \mathrm{msec}$ voltage steps that ranged from the holding potential of -64 to $+36 \mathrm{mV}$ in $20 \mathrm{mV}$ increments. Small outward currents that activated with depolarization and deactivated with hyperpolarization were apparent as early as E14 ( 300 pA at $36 \mathrm{mV}$ ) but became progressively larger at later developmental stages: up to $4 \mathrm{nA}$ at E19. Steady-state currents from each of the current families shown in Figure $3 A$ were sampled at the end of the voltage step (99 msecs) and were used to generate the $I-V$
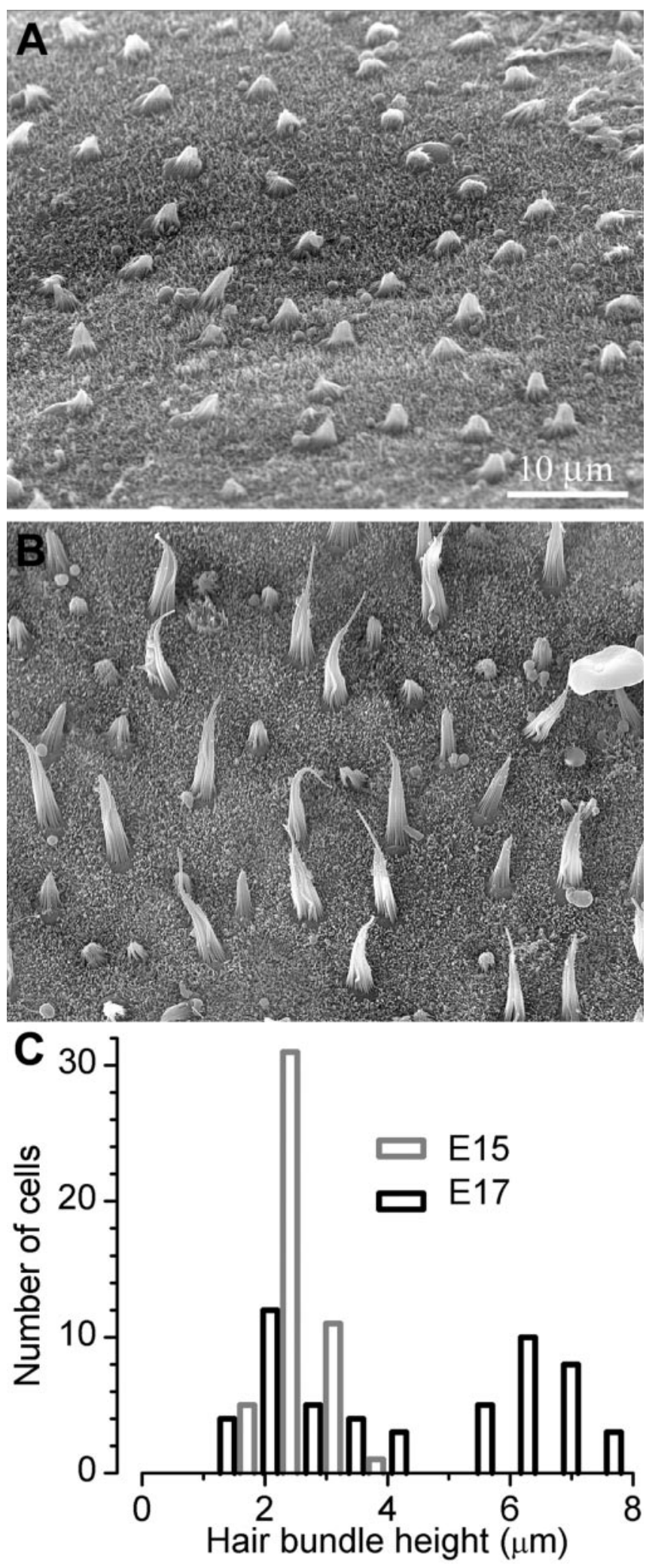

Figure 1. Scanning electron micrographs of embryonic hair bundles. $A$, Image of the sensory epithelium from the central region of an E15 mouse utricle. Forty-eight hair bundles are visible in this image. Scale bar: $A, B, 10 \mu \mathrm{m}$. $B$, SEM of the central region of an E17 mouse utricle. Hair bundles from both the first (tall) and second (short) wave of hair cell differentiation are visible. Note the red blood cell $(\sim 8 \mu \mathrm{m})$ in the upper right for scale. $C$, Histogram of bundle heights measured at E15 and E17. Bundle height was measured directly from the SEM image and taken to be the distance from cuticular plate to the tip of the tallest stereocilium. Bin width, $0.7 \mu \mathrm{m}$. 

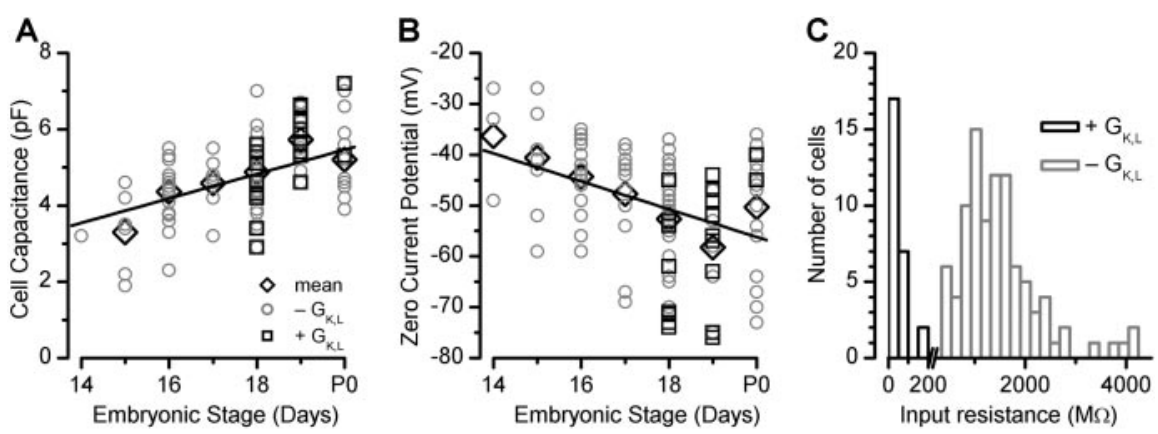

Figure 2. Membrane properties as a function of embryonic age. A, Cell capacitance was measured by electronic cancellation of the capacitive transient evoked by a $5 \mathrm{mV}$ step and is plotted as a function of developmental stage. At stages E18 to P0, cells that expressed $G_{K, L}$ are shown as squares. The diamonds show the mean values for all cells at each stage. The line is a linear regression fit to all data points $(r=0.53)$. B, Zero-current potential was taken as the intersection of the whole-cell steady-state $I-V$ relationship with the $x$-axis and is plotted as a function of developmental stage. At stages $E 18$ to $P 0$, cells that expressed $G_{K, L}$ are shown as dark squares. The diamonds show the mean values for all cells at each stage. The line is a linear regression fit to all data points $(r=0.38)$. C, Histogram of input resistance. Cells with $G_{K, L}$ are shown in black. To facilitate better resolution of the data, histogram bins below $200 \mathrm{M} \Omega$ were at $50 \mathrm{M} \Omega$ intervals and above $200 \mathrm{M} \Omega$ were at $200 \mathrm{M} \Omega$ intervals.

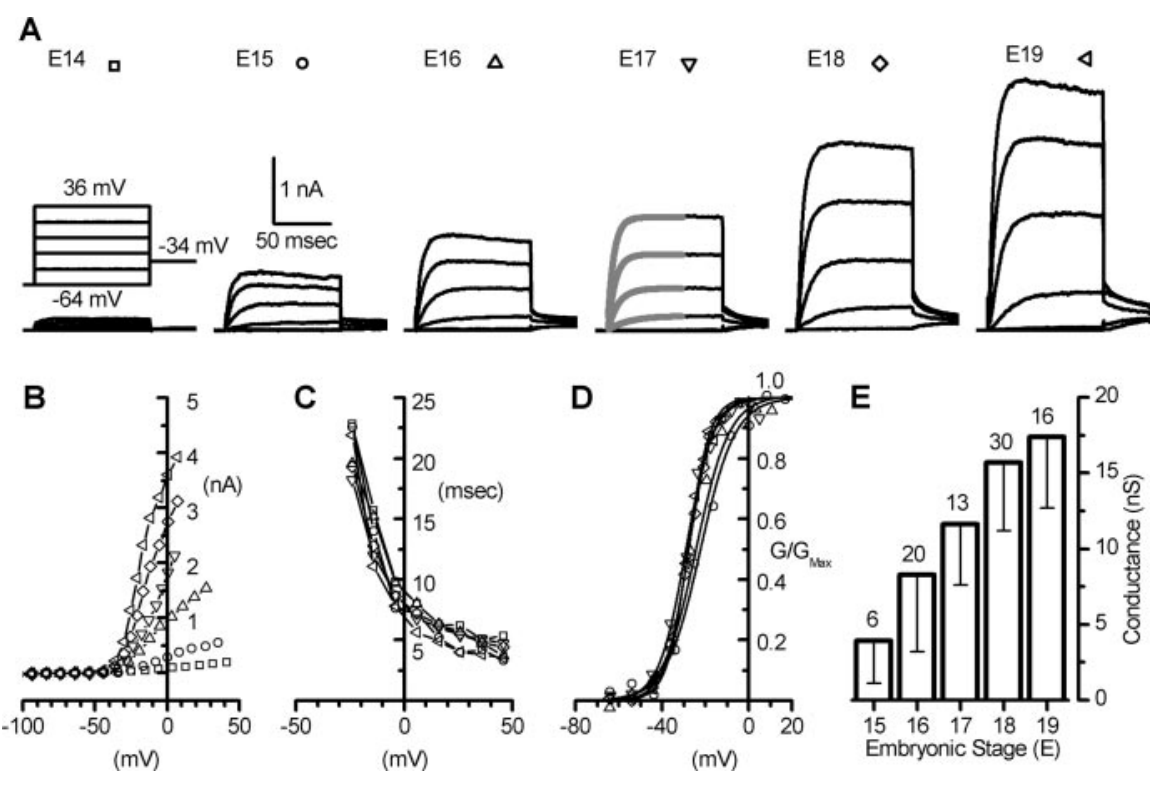

Figure 3. Developmental acquisition of the delayed rectifier potassium conductance. $A$, Representative families of outward potassium currents at several developmental stages as indicated above each family. The voltage protocol and calibration at the left applies to all current families. Fits of Equation 1 are shown for four traces at E17 (gray lines). B, Steady-state $I-V$ relationships taken from the data shown in $A$. The steady-state voltages have been corrected for junction potential and residual series resistance error. $C$, Time constants from the major component $\left(\tau_{1}\right)$ of fits of Equation 1 to the data shown in $A$. D, Activation curves derived from the data shown in $A$. Tail currents immediately after the step to $-34 \mathrm{mV}$ were normalized and plotted as a function of prepulse potential and fit with a first-order Boltzmann relation (Eq. 2).E, Bar graph of mean maximum chord conductance at each developmental stage. Error bars show SD. Number of cells is shown above each bar.

relationships shown in Figure $3 B$. The $I-V$ relationships revealed an increase in the current magnitude at all membrane potentials tested, suggesting a significant developmental increase in current expression. To identify the ion species that carried the currents, we estimated reversal potential using a voltage protocol that stepped to $16 \mathrm{mV}$ to maximally activate the outward current, followed by a family of voltage steps to potentials from -124 to $-14 \mathrm{mV}$. We used the current values immediately after the hyperpolarizing steps to generate instantaneous $I-V$ relationships (data not shown). The zero-current potential of the instantaneous $I-V$ relationships was taken as the reversal potential. We observed no systematic variation in reversal potential as a function of development and thus pooled the data to yield a mean reversal potential of $-71 \pm 10 \mathrm{mV}(n=$ 18), similar to the Nernst potential for potassium $(-81 \mathrm{mV})$, suggesting that these currents were carried primarily by potassium.

Current activation was well fit (Fig. $3 A$, E17, gray lines) with an equation used to describe the sigmoidal activation kinetics of delayed rectifier potassium currents in postnatal hair cells (Eq. 1) (Rüsch et al., 1998). Time constants from the major component of current activation $\left(\tau_{1}\right)$ are plotted as a function of membrane potential in Figure 3C. The kinetics of current activation became more rapid (i.e., smaller time constants) with larger depolarizations, similar to those of delayed rectifiers in postnatal type II hair cells (Rüsch et al., 1998), but did not vary as a function of development. The mean values ranged from $21 \pm 2 \mathrm{msec}$ at $-24 \mathrm{mV}$ to $4.2 \pm 0.8$ $\mathrm{msec}$ at $46 \mathrm{mV}(n=6)$.

To generate activation curves for the outward current, we used protocols identical to the one shown in Figure $3 A$. The tail currents at the instant of the step to $-34 \mathrm{mV}$ were divided by the driving force $(37 \mathrm{mV}$ ) to yield conductance, which was plotted as a function of prepulse potential (Fig. 3D). The data were fitted with a firstorder Boltzmann equation (Eq. 2) and normalized to facilitate comparison of slope and activation range. We observed no significant difference in the activation range, as determined by the voltage of halfmaximal activation (mean $V_{1 / 2}$ for all cells, $-28.7 \pm 5.5 \mathrm{mV} ; n=80$ ), nor in the voltage dependence, as determined by the slope factor (mean $s$ for all cells, $6.1 \pm 1.7$ $\mathrm{mV} ; n=80$ ). Last, we saw no evidence for inactivating potassium currents in any of 126 embryonic hair cells examined, suggesting that their acquisition occurs postnatally (Holt et al., 1998).

In summary, the most prominent systematic developmental change in the outward currents was the increase in amplitude, which was apparent in the whole-cell currents, the steady-state $I-V$ relationships, and the whole-cell conductances (Fig. $3 A, B, E$ ). There was a dramatic increase between E14 and E18, which began to plateau after E18 (data not shown). Because all other properties, including reversal potential, activation kinetics, voltage dependence, and voltage range of activation, were relatively consistent, we conclude that the increase in whole-cell current as a function of age is attributable to the progressive developmental acquisition of a homogeneous voltage-dependent potassium conductance. Furthermore, because the increase in cell capacitance (Fig. 2A) is accounted for by bundle growth, we assume the basolateral surface area remains relatively constant between E14 and P0, which implies that the increase in whole-cell conductance represents an increase in conductance density. Because a systematic variation in single-channel conductance as a 
A

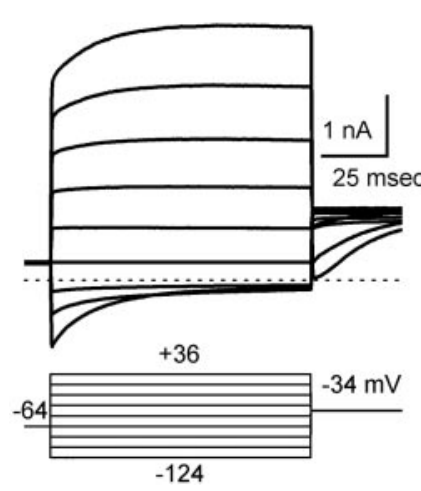

B

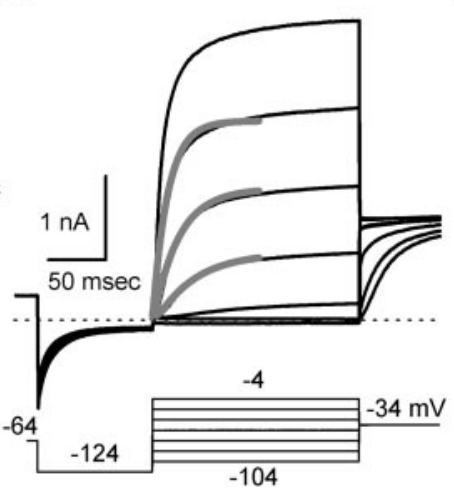

C

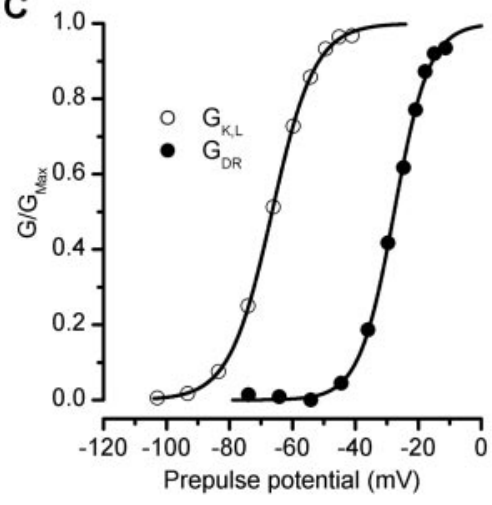

D

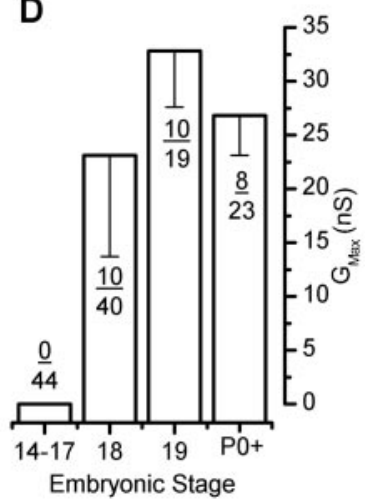

Figure 4. Acquisition of the low-voltage-activated conductance, $G_{\mathrm{K}, \mathrm{L}}$, at approximately $\mathrm{E} 18 . A$, A representative family of currents recorded from a putative type I hair cell. The voltage protocol (below) was identical to that used to evoke the currents in Figure 3. The dashed line shows the zero-current level. $B, A$ hyperpolarizing prepulse to $-124 \mathrm{mV}$ deactivated the currents that were active at rest. A subsequent family of depolarizations (bottom traces) was used to reactivate the currents. Same cell as in $A$. Fits of Equation 1 are superimposed on the three middle traces (gray lines). The dashed line indicates the zero-current level. C, Activation curves derived from the data shown in $B$ (open circles) and, for comparison, from the delayed rectifier conductance of a typical E18 hair cell (filled circles). Both datasets were fit with Boltzmann equations with a $V_{1 / 2}$ of -66 and $-28 \mathrm{mV}$, an s of 6.8 and $5.6 \mathrm{mV}$, and a $G_{\text {Max }}$ of 34 and $16 \mathrm{nS}$, respectively. $D$, Bar graph of mean maximum chord conductance for $G_{\mathrm{K}, \mathrm{L}}$ at each developmental stage. Only cells with $G_{\mathrm{K}, \mathrm{L}}$ were included in the mean. Error bars show SD. The fraction indicates the number of cells with $G_{\mathrm{K}, \mathrm{L}}$ over the number of cells studied at each stage. Note that the study was not done blind and that we sometimes targeted cells with type I morphological features. Therefore, the ratios do not represent the proportion of type I cells in the developing utricular epithelium.

function of age is unlikely, the parsimonious interpretation suggests that the increased density results from an increase in the number of functional potassium channels. Therefore, we suggest that the data can be best explained by the developmental acquisition of a homogeneous variety of voltage-dependent potassium channels with properties similar to the delayed rectifier seen in mature postnatal type II hair cells (Lang and Correia, 1989; Rennie and Ashmore, 1991; Masetto and Correia, 1997; Rüsch et al., 1998; Masetto et al., 2000; Brichta et al., 2002). However, we cannot exclude the possibility that the channels consist of a consistent ratio of heterogeneous channel subunits whose stoichiometry is tightly regulated.

\section{Low-voltage-activated potassium conductance}

We were surprised to note that 28 of 82 E18 to P2 cells revealed evidence of a conductance with striking similarity to the lowvoltage-activated potassium conductance, known as $G_{\mathrm{K}, \mathrm{L}}$ in mouse hair cells (Rüsch and Eatock, 1996; Rüsch et al., 1998; Chen and Eatock, 2000) and $G_{\mathrm{K} 1}$ in avian hair cells (Correia and Lang, 1990; Rennie and Correia, 1994). Previous reports suggested that $G_{\mathrm{K}, \mathrm{L}}$ was present only at P4 and later stages (Rüsch et al., 1998). We observed large instantaneous currents evoked by both hyperpolarization and depolarization, suggesting the presence of a conductance that was active at the holding potential of $-64 \mathrm{mV}$ (Fig. 4A). Indeed, these cells also had a very low input resistance (Fig. $2 C$, dark bars). Both the large instantaneous currents and the low-input resistance are hallmarks of $G_{\mathrm{K}, \mathrm{L}}$. The large inward currents evoked by hyperpolarization decayed toward baseline, presumably as the channels deactivated (Fig. $4 A, B)$. Subsequent depolarization activated the currents with sigmoidal kinetics that were well fit by Equation 1 with major time constants $\left(\tau_{1}\right)$ that ranged between 61 and $10 \mathrm{msec}$ (Fig. $4 B$, gray lines). Activation curves were generated by sampling the tail currents at the instant of a step to $-34 \mathrm{mV}$ and converting to conductance, which was plotted as a function of prepulse potential (Fig. 4C, open circles). The data were fitted with a first-order Boltzmann relation (Eq. 2) with a mean $V_{1 / 2}$ of $-62 \pm 5.8 \mathrm{mV}$ $(n=28)$, significantly more negative than the delayed rectifier conductance seen in the rest of the cells (Fig. $4 C$, filled circles).
The voltage sensitivity was similar to that of the other cells with a slope factor of $5.9 \pm 1.3 \mathrm{mV}$, and the mean maximal conductance was $27 \pm 8 \mathrm{nS}$. Based on inside-out recordings from postnatal rat type I hair cells, Chen and Eatock (2000) estimated the singlechannel conductance of $G_{\mathrm{K}, \mathrm{L}}$ was $29 \mathrm{pS}$. Using their value and our measurement of the whole-cell conductance for $G_{K, L}$, we estimated that approximately one-third of the E18-E19 hair cells expressed almost 1000 functional low-voltage-activated potassium channels and perhaps more if the their maximal open probability is less than one.

In postnatal vestibular epithelia, expression of $G_{\mathrm{K}, \mathrm{L}}$ is highly correlated with type I hair cells (Correia and Lang, 1990; Rennie and Correia, 1994; Ricci et al., 1996; Rüsch and Eatock, 1996; Rüsch et al., 1998). We found no evidence of $G_{\mathrm{K}, \mathrm{L}}$ in the 44 cells examined at stages earlier than E18 (Fig. 4D); thus, we wondered whether the presence of $G_{K, L}$ in embryonic hair cells indicated that the functional differentiation of type I hair cells begins at approximately E18. Indeed, some morphological features that characterize type I hair cells, such as a constricted neck region and partial calyces, were correlated with the presence of $G_{\mathrm{K}, \mathrm{L}}$. Whereas 22 of 28 cells with $G_{\mathrm{K}, \mathrm{L}}$ had clear type I morphological features, not all cells with type I morphologies had $G_{\mathrm{K}, \mathrm{L}}$. Therefore, we conclude that the functional maturation of type I cells, as indicated by the developmental acquisition of $G_{\mathrm{K}, \mathrm{L}}$, begins as early as E18 and proceeds throughout the first postnatal week until at approximately P8, the point at which Rüsch et al. (1998) reported type I cells reach their full adult morphology and physiology.

\section{Inward rectifier conductance}

In cells that lacked $G_{K, L}$, we found that hyperpolarizations from -64 to potentials between -84 and $-124 \mathrm{mV}$ evoked an instantaneous current followed by a fast activating inward current that inactivated for the most negative steps (Fig. 5A). This current was also evident in cells that expressed $G_{\mathrm{K}, \mathrm{L}}$, but, because it had a smaller amplitude than $G_{\mathrm{K}, \mathrm{L}}$ and an activation range that overlapped with $G_{\mathrm{K}, \mathrm{L}}$, we restricted our characterization to 106 cells that lacked $G_{K, L}$. Time constants of single-exponential fits to the time-dependent component of activation ranged from 0.8 to 4.4 
A

$\Delta \quad E 16$

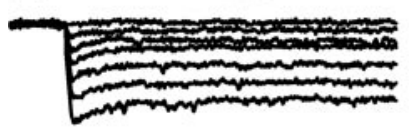

$\diamond \mathrm{E} 18$

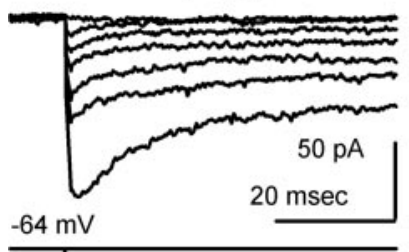

$\triangle \mathrm{P} 2$

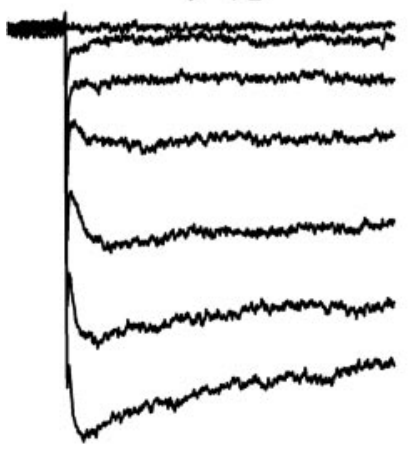

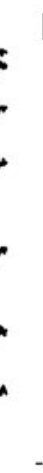
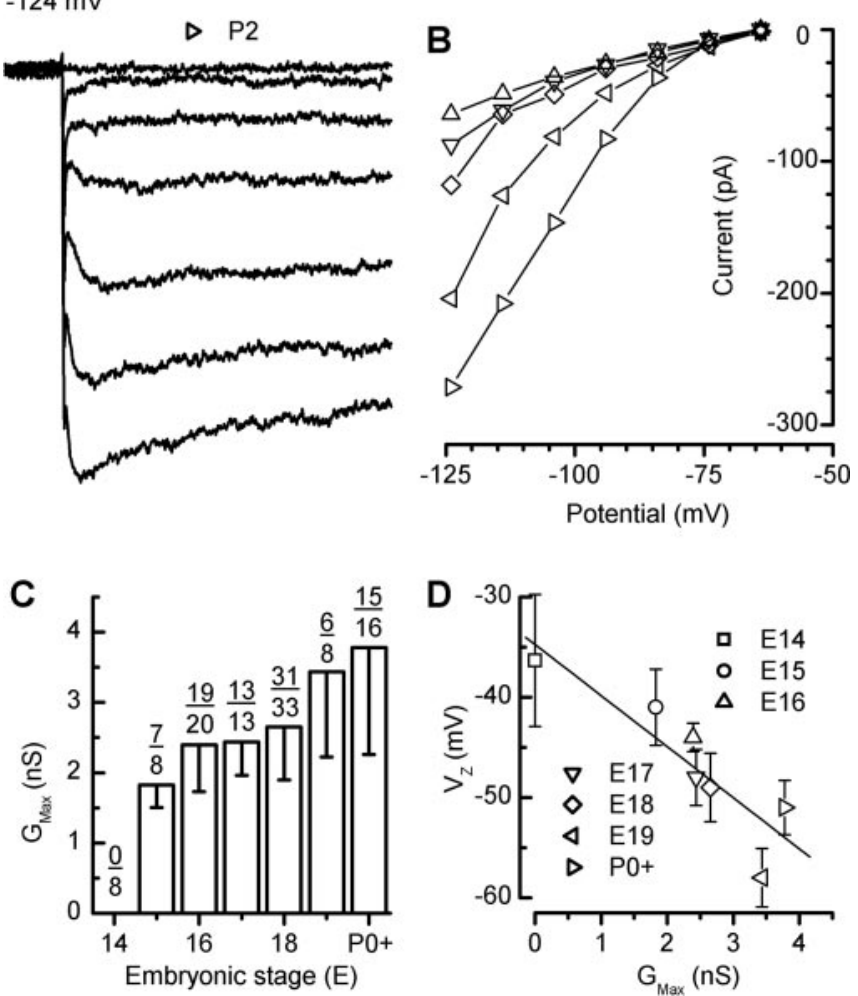

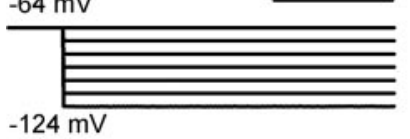

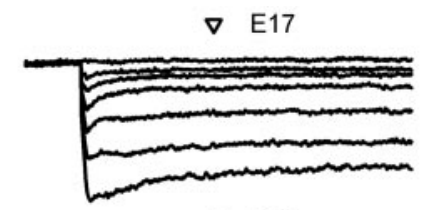

$\triangleleft \quad E 19$
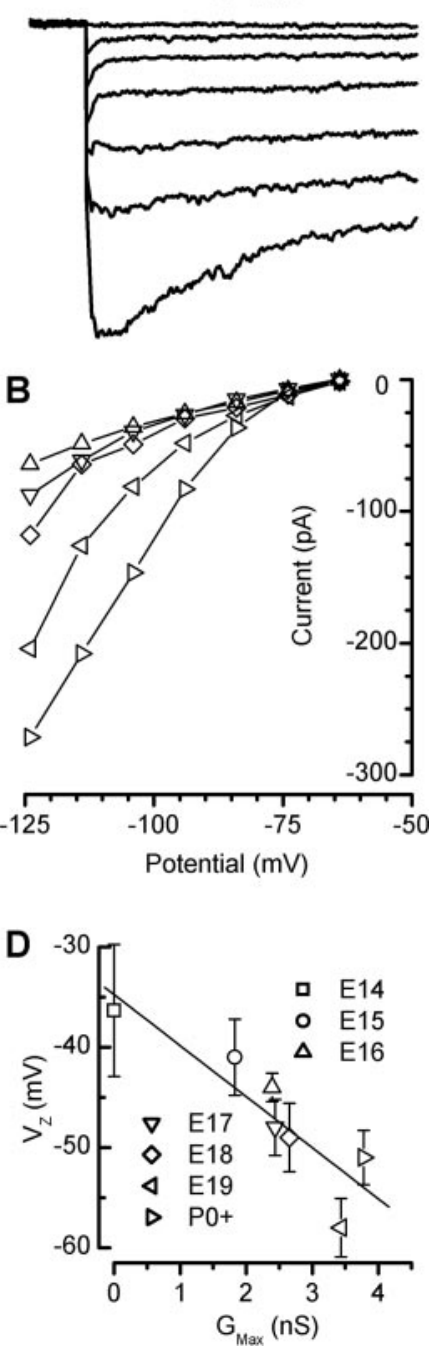

Figure 5. Representative families of inwardly rectifying currents at several developmental stages. $A$, Current families were evoked by series of $60 \mathrm{msec}$ voltage steps that ranged from -124 to $-64 \mathrm{mV}$ in $10 \mathrm{mV}$ increments (see protocol inset). Calibration applies to all datasets. $B$, Peak $I-V$ relationships for the data shown in $A$. C, The bar graph shows the mean maximal conductance for the inward rectifier at each embryonic stage. Only cells with $G_{K 1}$ were included in the mean. Error bars show SD. The fraction indicates the number of cells with $G_{\mathrm{K} 1}$ over the number of cells examined at each stage. $D$, Zero-current potential plotted as a function of the mean \pm SE maximum inward rectifier conductance for each embryonic stage. The line represents a linear regression fit to the data points.

msec for steps ranging from -124 to $-94 \mathrm{mV}$ in $10 \mathrm{mV}$ increments, respectively. After depolarization, the currents deactivated with submillisecond kinetics (data not shown) with properties similar to those described by Rüsch et al. (1998). The peak $I-V$ relationships (Fig. 5B) revealed pronounced rectification. Estimates of reversal potential confirmed that the currents were carried primarily by potassium. In terms of kinetics, activation range, and potassium selectivity, these currents were similar to those carried by the fast inward rectifier $G_{\mathrm{K} 1}$ found in postnatal mouse vestibular hair cells (Rüsch et al., 1998) and hair cells of other organs and species (Ohmori, 1984; Fuchs and Evans, 1990;
Masetto et al., 1994; Holt and Eatock, 1995; Sugihara and Furukawa, 1996; Marcotti et al., 1999; Brichta et al., 2002). To estimate the inward rectifier conductance, we used the peak current at $-124 \mathrm{mV}$ divided by driving force $\left(V_{M}-E_{1}=42 \mathrm{mV}\right)$. The inward rectifier conductance made its debut at E15 and gradually grew in magnitude over the subsequent neonatal week (Fig. $5 C$ ). Because outward current that flows through $G_{\mathrm{K} 1}$ between approximately $-40 \mathrm{mV}$, the onset of activation, and $E_{\mathrm{K}}(-82 \mathrm{mV})$ has been implicated as having a role in determining hair cell resting potential (Holt and Eatock, 1995; Goodman and Art, 1996), we were interested to note a correlation between zerocurrent potential and the maximum inward rectifier conductance (Fig. 5D). A linear regression fitted to a scatter plot of the mean zero-current potential verses the mean $G_{\mathrm{K} 1}$ at each embryonic stage had a slope of $-5.1 \mathrm{mV} / \mathrm{nS}(r=0.89)$, suggesting that acquisition of the embryonic inward rectifier shifts the hair cell resting potential toward more mature, hyperpolarized values.

In chick auditory hair cells, fast inward rectifier currents are thought to be carried by channels with a single-channel conductance of 17 pS (Navaratnam et al., 1995). If the currents in embryonic mouse vestibular cells express channels of similar conductance, it suggests that, by E15, 120 functional channels are assembled, and, over the subsequent week, approximately twice that number became functional. Because inward rectifiers are tetrameric, we suggest that embryonic hair cells are busy manufacturing at least 500-1000 protein monomers over this period to confer the functional conductance.

We found no evidence for the slow hyperpolarizationactivated inward current $I_{\mathrm{h}}$ first described in hair cells by Holt and Eatock (1995). Indeed, Rüsch et al. (1998) reported that $I_{\mathrm{h}}$ only appeared after P3.

\section{Sodium conductance}

We often observed small transient inward currents in hair cells at several embryonic stages (Fig. 6A). These rapidly activating, rapidly inactivating currents were evoked by step depolarizations positive to $-64 \mathrm{mV}$ that followed $100 \mathrm{msec}$ conditioning steps to $-124 \mathrm{mV}$. Current activation occurred with submillisecond kinetics and was followed by inactivation with $1-2$ msec kinetics. The peak currents were plotted in Figure $6 C$ as a function of step potential and were fitted with Equation 3 used to describe current-voltage relationships for sodium currents in outer hair cells (Oliver et al., 1997). We wondered whether these currents were carried by sodium or calcium; therefore, we began by replacing bath sodium with the impermeable monovalent cation $\mathrm{NMDG}^{+}$. After sodium replacement, the transient inward currents were $97 \pm 3 \%$ blocked in the six cells examined (Fig. 6B). After washout of $\mathrm{NMDG}^{+}$and return of sodium, the currents recovered to $61 \%$ of their original amplitude. We found the currents to be relatively insensitive to TTX. Bath application of TTX at concentrations between $300 \mathrm{~nm}$ and $1 \mathrm{~mm}$ revealed only a slight decrease in current amplitude in the six cells examined (maximum inhibition, 24\%), suggesting that the sodium conductance expressed in embryonic hair cells is TTX resistant, unlike that expressed in mouse auditory hair cells (Marcotti et al., 2003) and chick vestibular hair cells (Masetto et al., 2003). To estimate the voltage dependence of the sodium conductance activation, we used the peak currents divided by the driving force for sodium $\left(V_{\mathrm{M}}-\right.$ $\left.E_{\mathrm{Na}}\right)$. The data were plotted as a function of step potential and fitted with a first-order Boltzmann equation (Eq. 2). Because inactivation followed activation with little delay, the maximal conductance values obtained by this method probably underestimated the true maximal conductance. Therefore, we normal- 
ized the curves to $G_{\mathrm{Max}}$ to facilitate comparison of $V_{1 / 2}$ and slope factors (Fig. $6 D$, filled circles). We observed no systematic variation in $V_{1 / 2}$ or $s$ as a function of developmental stage and pooled the data. The mean $V_{1 / 2}$ of activation was $-40 \pm 5.3$ $\mathrm{mV}$, with a mean slope factor of $4.9 \pm 1.2$ $\mathrm{mV}(n=56)$. We examined the voltage dependence of inactivation using a step to $-34 \mathrm{mV}$ that followed a family of steps that ranged between -104 and $-64 \mathrm{mV}$ in $10 \mathrm{mV}$ increments. The peak currents at $-34 \mathrm{mV}$ were converted to conductances, plotted as a function of prepulse potential and fitted with a Boltzmann equation (Fig. $6 D$, open circles). Similar to activation, we noted no developmental variation in the voltage dependence of inactivation: the $V_{1 / 2}$ of inactivation was $-88 \pm 6.1 \mathrm{mV}$, with a slope factor of $6.0 \pm 1.7 \mathrm{mV}(n=$ 50 ). The inactivation curve revealed a conundrum: in contrast to the sodium conductance in auditory hair cells (Marcotti et al., 2003), the embryonic vestibular sodium conductance was almost entirely inactivated at the typical resting potentials of embryonic hair cells, suggesting that it probably has little impact on the hair cell receptor potential. Further confounding interpretation was the transient expression we observed. Both the number of hair cells expressing the sodium conductance and the conductance magnitude peaked between E16 and E18 and then declined to near zero shortly after birth (Fig. 6E). Because we found that expression of the sodium conductance was declining at approximately the same time frame that $G_{\mathrm{K}, \mathrm{L}}$ expression was rising (E18 to P0), we expected little overlap in these two subsets of embryonic hair cells. Indeed, of the 28 cells with $G_{\mathrm{K}, \mathrm{L}}$, only seven expressed $G_{\mathrm{Na}}$.

Transient expression of sodium currents has been documented in auditory hair cells (Evans and Fuchs, 1987; Witt et al., 1994; Oliver et al., 1997; Marcotti et al., 2003) but has not been widely reported in vestibular cells (Masetto et al., 2003). One preliminary report suggested the presence of TTX-resistant sodium currents in mammalian vestibular hair cells (Rüsch and Eatock, 1997). In other cell types, TTX-resistant sodium channels have a single-channel conductance of $\sim 20 \mathrm{pS}$ (Undrovinas et al., 2002). If embryonic vestibular hair cell sodium currents are carried by channels with a similar conductance, we estimate that, between E16 and E18, they express as many as 100 functional sodium channels.

\section{Receptor potentials}

In the previous sections, we described the developmental acquisition of four distinct conductances: $G_{\mathrm{DR}}, G_{\mathrm{K}, \mathrm{L}}, G_{\mathrm{K} 1}$, and $G_{\mathrm{Na}}$. In this section, we take a different approach and evaluate the contribution of each conductance to the hair cell receptor potential evoked by current steps and previously recorded transduction currents. The transduction currents were recorded in response to $\sim 2 \mu$ m peak-to-peak sine waves (Holt et al., 1997) and had amplitudes similar to the mean maximal transduction currents in embryonic hair cells (Géléoc and Holt, 2003). The aim of this approach was to correlate changes in the receptor potential waveform with the acquisition of each conductance and, in doing so, identify the functional contribution of these four conductances.

We found that the delayed rectifier potassium conductance activated positive to $-40 \mathrm{mV}$, and its mean amplitude more than tripled between E15 and E19 (Fig. 3E). Accordingly, we predicted that acquisition of $G_{\mathrm{DR}}$ would have little effect on small current injections that did not depolarize the cell positive to $-40 \mathrm{mV}$. However, our expectation was that, for large depolarizations of sufficient duration ( $\tau$ values of activation ranged from 10 to 20 $\mathrm{msec}), G_{\mathrm{DR}}$ would activate and repolarize the membrane potential; furthermore, we hypothesized that this effect would be more pronounced at later stages. Indeed, at high frequencies, the depolarizing phase was of insufficient duration, and we noted little difference in the response to $100 \mathrm{~Hz}$ transduction currents at E15 and E18 (Fig. 7). However, at both E15 and E18, we noted that the first cycle of the five cycle burst often had a larger amplitude than the subsequent cycles. We attribute this effect to the cumulative activation of $G_{D R}$ with each cycle, which tended to lower the membrane resistance and in turn attenuated the amplitudes of the peak-to-peak receptor potentials by $5-10 \mathrm{mV}$. At lower frequencies $(10 \mathrm{~Hz})$, activation of $G_{\mathrm{DR}}$ within the depolarizing phase of each cycle clearly attenuated the peaks of the receptor potential (large arrows) with a greater reduction in amplitude at later stages (E18). At $1 \mathrm{~Hz}$, the activation kinetics of $G_{\mathrm{DR}}$ were faster than the rise time of the current stimuli, and thus $G_{\mathrm{DR}}$ clipped the peaks of the depolarizing phase entirely. The greater magnitude 

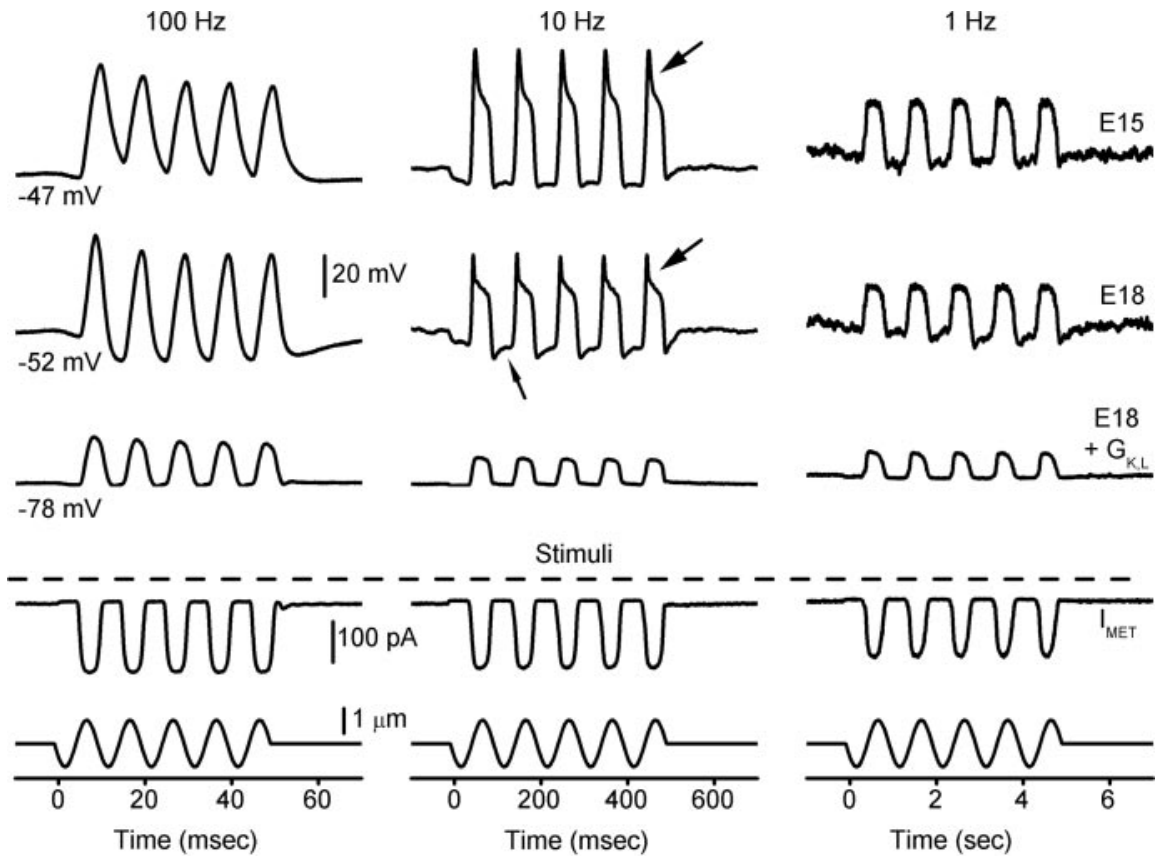

Figure 7. Receptor potentials evoked by injecting previously recorded transduction currents. The transduction currents were recorded from a postnatal day 8 , type $\mathrm{II}$ hair cell in response to five cycles of 100,10 , and $1 \mathrm{~Hz}$ sinusoidal hair bundle deflections ( $\sim 2 \mu \mathrm{m}$ peak-to-peak). The current amplitudes ranged from -170 to $-134 \mathrm{pA}$, similar to the mean maximal transduction current recorded from E17 hair cells (Géléoc and Holt, 2003). The resting potentials for each series is indicated at the left. Calibration applies to all traces. The top three traces were recorded from an E15 hair cell. The large arrow indicates the repolarizing influence of the delayed rectifier conductance. The middle traces were recorded from an E18 hair cell stimulated at 100, 10, and 1 $\mathrm{Hz}$. The repolarizing influence of delayed rectifier activation (large arrow) and inward rectifier activation (small arrow) are indicated. The bottom three traces were recorded from an E18 hair cell that expressed $G_{K, L}$. The transduction current stimuli, injected in current-clamp mode, and the sine wave bundle deflections used to evoke them are shown below. of $G_{\mathrm{DR}}$ in the E18 cell is evident in the smaller peak-to-peak amplitude of the receptor potential at $1 \mathrm{~Hz}: 27 \mathrm{mV}$ as opposed to $35 \mathrm{mV}$ at E15.

Because $G_{\mathrm{K}, \mathrm{L}}$ was active at rest $\left(V_{1 / 2}\right.$ of $-62 \mathrm{mV}$ ), it had a significant impact on the input resistance and zero-current potential (Fig. $2 B, C$ ). We predicted that the cells that acquired $G_{\mathrm{K}, \mathrm{L}}$ at E18 would have more negative resting potentials and that their response to current injections would be attenuated relative to younger cells and cells that lacked $G_{\mathrm{K}, \mathrm{L}}$. Figure 7 shows traces at 100,10 , and $1 \mathrm{~Hz}$ recorded from an E18 cell that expressed $G_{\mathrm{K}, \mathrm{L}}$. As expected, E18 and older cells that had $G_{\mathrm{K}, \mathrm{L}}$, had significantly more hyperpolarized resting potentials: $-78 \mathrm{mV}$ as opposed to $-52 \mathrm{mV}$ in the E18 cell that lacked $G_{\mathrm{K}, \mathrm{L}}$ (Fig. 7). Furthermore, receptor potential amplitudes at all frequencies tested were significantly reduced in E18 cells with $G_{\mathrm{K}, \mathrm{L}}$ relative to those that lacked $G_{\mathrm{K}, \mathrm{L}}$. In the examples of Figure 7, the peak-to-peak receptor potential amplitudes at $100 \mathrm{~Hz}$ were reduced from 64 to $25 \mathrm{mV}$ in E18 cells without and with $G_{\mathrm{K}, \mathrm{L}}$, respectively, and from 52 to 13 $\mathrm{mV}$ at $10 \mathrm{~Hz}$. At $1 \mathrm{~Hz}$, the difference was less pronounced because of the significant activation of $G_{\mathrm{DR}}$ at the lower frequency: $25 \mathrm{mV}$ for the cell without $G_{\mathrm{K}, \mathrm{L}}$ as opposed to $13 \mathrm{mV}$ for the cell with $G_{\mathrm{K}, \mathrm{L}}$.

In 106 cells that lacked $G_{K, L}$, the fast inward rectifier $G_{\mathrm{K} 1}$ was the dominant membrane conductance active at rest. Consistent with that notion was the observation that acquisition of the inward rectifier conductance between E15 and P0 was highly correlated with a negative shift in the zerocurrent potential (Fig. 5D). Likewise, we predicted a similar negative shift in resting potential that paralleled acquisition of $G_{\mathrm{K} 1}$. In addition, we predicted that development of $G_{\mathrm{K} 1}$ would attenuate the membrane response to hyperpolarizing current injections. Relative to the E15 cell that lacked $G_{\mathrm{K} 1}$, we noted a more hyperpolarized resting potential in the E18 cell, and we often observed repolarization during the hyperpolarizing phase of the receptor potential (Fig. 7, E18, small arrow, $10 \mathrm{~Hz}$ ), consistent with activation of an inward rectifier or deactivation of the larger $G_{\mathrm{DR}}$ expressed at E18.

In contrast to developing inner hair cells from the organ of Corti (Marcotti et al., 2003), vestibular hair cells do not exhibit spontaneous sodium-dependent action potentials. Furthermore, because the vestibular hair cell sodium conductance was almost entirely inactivated (Fig. 6D) at typical resting potentials (range, -50 to $-70 \mathrm{mV}$ ), we predicted that expression of $G_{\mathrm{Na}}$ would have little impact on the voltage response to depolarizing current steps from rest. Indeed, when we delivered depolarizing current steps from the resting potential, we were unable to evoke action potentials in any of the 18 cells examined, all of which expressed the embryonic sodium conductance. Figure $8 \mathrm{~A}$ shows an example of the typical response to a current step of $-25 \mathrm{pA}$, which evoked a small passive depolarization (arrow) followed by repolarization that presumably resulted from activation of outward rectifier potassium conductances. We further hypothesized that, if inward current steps were preceded by hyperpolarizing steps,
Figure 8. Membrane potential spikes evoked by current steps in embryonic hair cells. Calibration applies to all traces. Resting potentials are indicated. $A$, Current-clamp response of an E16 cell stimulated with a -25 pA current step (protocol shown below). $B$, The same cell as in $A$ was stimulated with a $15 \mathrm{pA}$ prepulse to hyperpolarize the cell to $-81 \mathrm{mV}$. Note the small passive depolarization with the step to $-25 \mathrm{pA}$ was similar to that of trace $A$ (small arrows). $C$, The same cell as in $A$ and $B$ injected with a $100 \mathrm{pA}$ prepulse to hyperpolarize the cell and relieve $G_{\mathrm{Na}}$ inactivation. With the step to $-25 \mathrm{pA}$, the cell evoked spike-like behavior (large arrow). $D$, Control trace from a different $\mathrm{E} 16$ cell. The protocol (below) was identical to that of $C$. $E$, The same cell and protocol as shown in $D$ after bath exchange of sodium for NMDG ${ }^{+}$to confirm the spike behavior was the result of $G_{\mathrm{Na}}$ activation. $F, A$ control trace from an $E 19$ cell that lacked $G_{\mathrm{Na}}$ and spike behavior. 
$G_{\mathrm{Na}}$ inactivation would be relieved and that, after the inward steps, the membrane would enter a depolarizing phase accentuated by $I_{\mathrm{Na}}$-induced positive feedback. As expected, we found that, when inward steps of $-25 \mathrm{pA}$ were preceded by outward current steps of sufficient magnitude (100 pA) to hyperpolarize the cell negative to approximately $-100 \mathrm{mV}$, active spike-like behavior with peaks close to $0 \mathrm{mV}$ were evoked (Fig. $8 C, D$ ). That the spikes were the result of an active process rather than a passive depolarization is indicated by the inflection in the membrane potential waveform (Fig. $8 C, D$, arrows). The spike behavior was abolished by substitution of external sodium with the impermeable cation $\mathrm{NMDG}^{+}$(Fig. $8 E$ ), confirming that spike was the result of the sodium conductance activation. Likewise, the spikes were also absent in E19 cells that lacked $G_{\mathrm{Na}}$ entirely (Fig. $8 F$ ).

In an attempt to relieve sodium conductance inactivation under more physiological conditions, we delivered hyperpolarizing current steps of $15 \mathrm{pA}$, approximately equivalent to that induced by closure of a couple of mechanotransduction channels (i.e., the 5-10\% open at rest). This step amplitude was also selected to hyperpolarize the cell to $-81 \mathrm{mV}$, the potassium equilibrium potential, but not beyond. We reasoned that, under physiological conditions, cells would rarely hyperpolarize negative to $E_{\mathrm{K}^{+}}$. Step durations of $150 \mathrm{msec}$ (Fig. 8 B) or $300 \mathrm{msec}$ (data not shown) were chosen to allow recovery from inactivation to reach steady state. At $-80 \mathrm{mV}$, time constants for recovery from hair cell sodium channel inactivation are $\sim 42 \mathrm{msec}$ (Masetto et al., 2003). During depolarization, with a family of currents steps that ranged from -15 to $-185 \mathrm{pA}$, the amplitude range of typical mechanotransduction currents, we observed no active spike behavior (Fig. $8 B$, arrow) in any of the cells examined, all of which expressed the sodium conductance. Therefore, we conclude that the embryonic sodium conductance in vestibular hair cells does not contribute to the hair cell receptor potential waveform in a physiologically significant manner, which is most likely the result of its negatively shifted inactivation range.

\section{Discussion}

\section{A developmental timeline}

We characterized the developmental acquisition of four physiologically defined, voltage-gated conductances and, in a previous study (Géléoc and Holt, 2003), acquisition of the mechanoelectric transduction conductance. In Figure 9, we present a timeline that charts the developmental acquisition of all five conductances as a function of embryonic age. If we assume that the first wave of hair cell development begins at E12 (Ruben, 1967) and define this as zero, we can chart conductance acquisition as a function of hair cell age (top axis). We hypothesize that hair cell physiological development follows a stereotyped pattern of conductance acquisition as a function of hair cell age, with physiological differentiation into type I and type II cells beginning as early as hair cell age 6 (E18 for first-wave hair cells). To test our hypothesis, we recorded from several cells that were members of the second wave as determined by their shorter bundle height and more peripheral location. The inset shows a family of currents recorded from one such E19 hair cell. The currents revealed evidence of small delayed rectifier, inward rectifier, and sodium conductances, inconsistent with first-wave, E19 hair cells. However, based on its electrophysiological profile, this cell appeared to be approximately hair cell age 3, which would suggest that it was born at approximately E16. This is consistent with the morphological development of the second wave of hair cell maturation, which begins at approximately E15-E16 (Denman-Johnson and Forge, 1999),

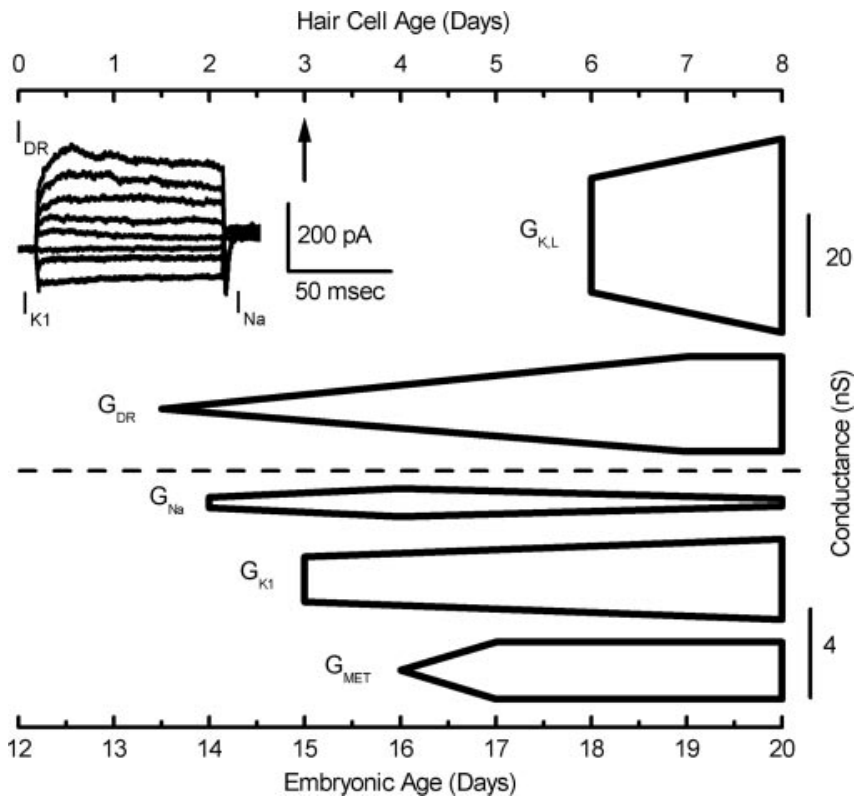

Figure 9. Developmental timeline of hair cell voltage-sensitive and mechanosensitive conductance acquisition. The mean maximal conductance is plotted as a function of embryonic stage (bottom axis). The top axis plots conductance acquisition as a function of hair cell age. The $4 \mathrm{nS}$ calibration bar applies below the dashed line, and the $20 \mathrm{nS}$ calibration bar applies above the line. The inset shows a family of currents recorded from a second-wave E19 hair cell evoked by 100 msec steps from - 104 to $36 \mathrm{mV}$ in $20 \mathrm{mV}$ increments. Based on the expression of small delayed rectifier $\left(I_{\mathrm{DR}}\right)$, inward rectifier $\left(I_{\mathrm{K} 1}\right)$, and sodium $\left(I_{\mathrm{Na}}\right)$ currents, we estimate this cell was $\sim 3$ d old (arrow).

and supports our notion of a stereotyped pattern of physiological development.

Interestingly, in a previous report, Rüsch et al. (1998) suggested the low-voltage-activated conductance, $G_{\mathrm{K}, \mathrm{L}}$, began to appear at approximately postnatal days 3-4. Our data suggest that $G_{\mathrm{K}, \mathrm{L}}$ begins to appear at E18. We present the following as a possible explanation for the apparent discrepancy. If Rüsch et al. (1998) recorded selectively from hair cells of the second wave, which were born at approximately E16, they would be hair cell age 6 at approximately P3, exactly the hair cell age at which we observed the onset of $G_{\mathrm{K}, \mathrm{L}}$ expression in first-wave cells (Fig. 9). Likewise, we found evidence of $G_{\mathrm{K}, \mathrm{L}}$ expression in some peripheral type I cells at P3 (data not shown). Both observations further support our notion of a stereotyped pattern of hair cell functional maturation.

\section{Molecular identification of hair cell conductances}

The precisely defined developmental timeline of membrane conductance acquisition presented in the previous section provides an opportunity for identification of the ion channel genes whose expression underlies the physiologically defined conductances. Ion channel genes with a temporal expression pattern that parallels the conductance acquisition pattern can be advanced to the top of the list of potential candidates, as demonstrated recently for the hair cell transduction channel (Corey et al., 2004). Whereas channel genes whose expression precedes conductance acquisition cannot be ruled out, those that lag conductance acquisition can be excluded from further consideration.

For example, Holt and Corey (1999) and others (Kharkovets et al., 2000; Trussell, 2000; Rennie et al., 2001) have suggested that $G_{\mathrm{K}, \mathrm{L}}$ may consist of KCNQ4 and/or KCNQ3 subunits. If indeed the case, we predict that onset of KCNQ subunit expression will 
coincide with or precede $G_{\mathrm{K}, \mathrm{L}}$ expression. If KCNQ expression precedes $G_{\mathrm{K}, \mathrm{L}}$, it would raise the possibility that the channel subunits are modified at approximately E18 such that their activation range is shifted to more negative potentials. Modification of a preexisting channel might result from coassembly with $\beta$ subunits or posttranslational modifications, such as phosphorylation or modulation by second messengers (Chen and Eatock, 2000).

\section{Receptor potentials}

Previous studies of the hair cell receptor potential have used computer models (Hudspeth and Lewis, 1988b; Holt and Eatock, 1995; Catacuzzeno et al., 2003) or pharmacological blockade (Fuchs and Evans, 1990; Masetto et al., 1994; Goodman and Art, 1996; Marcotti et al., 1999) to examine the contributions of ionic conductances. By correlating conductance acquisition with changes in the receptor potential waveform, we have taken an alternative approach to establish a link between each ionic conductance and its specific role in sensory signaling.

We found that the gradual acquisition of $G_{\mathrm{DR}}$ between E14 and E19 attenuated the peaks of depolarizations positive to approximately $-40 \mathrm{mV}$ but only for low frequencies, which allowed sufficient time for the relatively slow activation kinetics of $G_{\mathrm{DR}}$. Because of its significant activation at rest, acquisition of $G_{\mathrm{K}, \mathrm{L}}$ at E18 had a profound impact on resting potential and the amplitude of the receptor potential. Cells that acquired $G_{\mathrm{K}, \mathrm{L}}$ at E18 and later stages had resting potentials $\sim 25 \mathrm{mV}$ more negative and maximal receptor potentials of only $10-15 \mathrm{mV}$. In cells that lacked $G_{\mathrm{K}, \mathrm{L}}$, gradual acquisition of $G_{\mathrm{K} 1}$ between E15 and P0 was correlated with a gradual negative shift in the zero-current potential. In addition, we found that $G_{\mathrm{K} 1}$ acquisition attenuated the peaks during the hyperpolarizing phase of the receptor potential waveform.

Last, we conclude that expression of $G_{\mathrm{Na}}$ does not have a significant impact on the receptor potential in our in vitro recording conditions. $G_{\mathrm{Na}}$ in embryonic vestibular hair cells is almost completely inactivated at typical resting potentials, suggesting that it is physiologically silent, similar to the sodium conductance in outer hair cells (Witt et al., 1994). However, we cannot exclude the possibility that the in vivo properties differ from those we described in vitro. For example, if the inactivation curve is shifted more positively, a greater proportion of $G_{\mathrm{Na}}$ may be available for activation. In cardiac cells, kinases have been shown to shift the voltage dependence of a TTX-resistant sodium conductance (Watson and Gold, 1997; Gold et al., 1998). Given a similar shift, we demonstrated that $G_{\mathrm{Na}}$ in embryonic vestibular hair cells is of sufficient magnitude to evoke spiking behavior akin to that of developing inner hair cells, in which it is hypothesized to be a pacemaker and drive synaptogenesis and functional maturation further downstream in the auditory system (Kros et al., 1998; Marcotti et al., 2003).

\section{Functional significance}

We demonstrated that changes in the conductance expression pattern affect the sensory receptor potential, but whether these changes have functional significance for vestibular system development or they simply represent the sequence through which hair cells must pass on the road to maturity is not clear. Several possible functions come to mind. Innervation of embryonic vestibular epithelia begins as early as E15, and functional synaptogenesis of bouton afferents with type II cells might follow shortly thereafter (Mbiene et al., 1988). Because vestibular hair cells become mechanosensitive at E17 (Géléoc and Holt, 2003), we pre- dict that the developmental shift in resting potential to more hyperpolarized values will yield larger transduction currents and, in turn, larger receptor potentials. Together with the self-evident notion that vestibular stimuli impinge on the developing embryo, the possibility exists that sensory-driven receptor potential activity may underlie functional maturation within the vestibular system in a manner similar to but distinct from the stimulus-independent, spontaneous activity proposed to drive development in the auditory (Kros et al., 1998) and visual systems (Shatz, 1996).

Formation of partial calyces around type I cells were reported as early as E18 (Van De Water et al., 1978), the same stage that we noted the onset of $G_{\mathrm{K}, \mathrm{L}}$ expression. This raises an interesting, but reciprocal, question: does calyx formation induce $G_{\mathrm{K}, \mathrm{L}}$ expression and type I cell differentiation or vise versa? Rüsch et al. (1998) concluded that calyceal endings were not required for $G_{\mathrm{K}, \mathrm{L}}$ expression based on their observation that $G_{\mathrm{K}, \mathrm{L}}$ acquisition in deafferented, organotypic cultures from postnatal mouse utricles paralleled the endogenous time course. However, we cannot rule out the possibility that a causal relationship exists: perhaps $G_{\mathrm{K}, \mathrm{L}}$ expression and type I cell differentiation induces calyx formation. Furthermore, because it has been suggested that $\mathrm{K}^{+}$accumulation in the synaptic cleft may mediate a novel form of synaptic transmission between the type I cell and its afferent calyx (Goldberg, 1996), the tight temporal correlation we report here raises the possibility that type I synapses may become functional around this time frame.

\section{Summary and conclusion}

We demonstrated that hair cells undergo a dramatic period of functional maturation beginning as early as embryonic day 14 in the mouse utricle. Over the subsequent prenatal week, maturing hair cells acquire at least four distinct voltage-gated conductances, $G_{\mathrm{DR}}, G_{\mathrm{K}, \mathrm{L}}, G_{\mathrm{K} 1}$, and $G_{\mathrm{Na}}$, and the mechanotransducer conductance. We present a timeline of conductance acquisition and propose that embryonic hair cells follow a stereotyped pattern of functional maturation. In addition, we find that the physiological differentiation into type I and type II cells begins as early as E18 with the acquisition of the type I specific, low-voltageactivated potassium conductance, $G_{\mathrm{K}, \mathrm{L}}$. Other membrane conductances may also be acquired during this time frame, including, but not limited to, voltage-gated calcium (Hudspeth and Lewis, 1988a; Platzer et al., 2000; Bao et al., 2003; Song et al., 2003) and chloride conductances and ligand-gated conductances such as those gated by ATP (for review, see Housley, 2000), or acetylcholine (Fuchs and Murrow, 1992; Elgoyhen et al., 1994, 2001). Last, we suggest that replication of the physiological profile through which embryonic hair cells develop (Fig. 9) in candidate regenerated hair cells (Lawlor et al., 1999; Shou et al., 2003) will help validate their advancement to the enviable status of fully functional hair cell.

\section{References}

Bao H, Wong WH, Goldberg JM, Eatock RA (2003) Voltage-gated calcium channel currents in type I and type II hair cells isolated from the rat crista. J Neurophysiol 90:155-164.

Brichta AM, Aubert A, Eatock RA, Goldberg JM (2002) Regional analysis of whole cell currents from hair cells of the turtle posterior crista. J Neurophysiol 88:3259-3278.

Catacuzzeno L, Fioretti B, Franciolini F (2003) Voltage-gated outward K currents in frog saccular hair cells. J Neurophysiol 90:3688-3701.

Chen JW, Eatock RA (2000) Major potassium conductance in type I hair 
cells from rat semicircular canals: characterization and modulation by nitric oxide. J Neurophysiol 84:139-151.

Corey DP, Garcia-Anoveros J, Holt JR, Kwan KY, Lin SY, Vollrath MA, Amalfitano A, Cheung E, Derfler BH, Duggan A, Géléoc GSG, Gray P, Hoffman MP, Rehm HL, Tamasauskas D, Zhang DS (2004) TRPA1 is a candidate for the mechanosensitive transduction channel of vertebrate hair cells. Nature, in press.

Correia MJ, Lang DG (1990) An electrophysiological comparison of solitary type I and type II vestibular hair cells. Neurosci Lett 116:106-111.

Davidson D, Baldock R, Kaufman M, Bard J (2002) Edinburgh Mouse Atlas Project, Medical Research Council Human Genetics Unit, Edinburgh, UK. Available at http://genex.hgu.mrc.ac.uk.

Denman-Johnson K, Forge A (1999) Establishment of hair bundle polarity and orientation in the developing vestibular system of the mouse. J Neurocytol 28:821-835.

Eatock RA, Hurley KM (2003) Functional development of hair cells. Curr Top Dev Biol 57:389-448.

Elgoyhen AB, Johnson DS, Boulter J, Vetter DE, Heinemann S (1994) Alpha 9: an acetylcholine receptor with novel pharmacological properties expressed in rat cochlear hair cells. Cell 79:705-715.

Elgoyhen AB, Vetter DE, Katz E, Rothlin CV, Heinemann SF, Boulter J (2001) Alpha10: a determinant of nicotinic cholinergic receptor function in mammalian vestibular and cochlear mechanosensory hair cells. Proc Natl Acad Sci USA 98:3501-3506.

Evans MG, Fuchs PA (1987) Tetrodotoxin-sensitive, voltage-dependent sodium currents in hair cells from the alligator cochlea. Biophys J 52:649-652.

Fuchs PA, Evans MG (1990) Potassium currents in hair cells isolated from the cochlea of the chick. J Physiol (Lond) 429:529-551.

Fuchs PA, Murrow BW (1992) Cholinergic inhibition of short (outer) hair cells of the chick's cochlea. J Neurosci 12:800-809.

Géléoc GS, Holt JR (2003) Developmental acquisition of sensory transduction in hair cells of the mouse inner ear. Nat Neurosci 10:1019-1020.

Gold MS, Levine JD, Correa AM (1998) Modulation of TTX-R $I_{\mathrm{Na}}$ by PKC and $\mathrm{PKA}$ and their role in $\mathrm{PGE}_{2}$-induced sensitization of rat sensory neurons in vitro. J Neurosci 18:10345-10355.

Goldberg JM (1996) Theoretical analysis of intercellular communication between the vestibular type I hair cell and its calyx ending. J Neurophysiol 76:1942-1957.

Goodman MB, Art JJ (1996) Positive feedback by a potassium-selective inward rectifier enhances tuning in vertebrate hair cells. Biophys J 71:430-442.

Holt JR, Corey DP (1999) Ion channel defects in hereditary hearing loss. Neuron 22:217-219.

Holt JR, Eatock RA (1995) Inwardly rectifying currents of saccular hair cells from the leopard frog. J Neurophysiol 73:1484-1502.

Holt JR, Corey DP, Eatock RA (1997) Mechanoelectrical transduction and adaptation in hair cells of the mouse utricle, a low frequency vestibular organ. J Neurosci 17:8739-8748.

Holt JR, Vollrath MA, Eatock RA (1998) Stimulus processing by type II hair cells in the mouse utricle. Ann NY Acad Sci 871:15-26.

Housley GD (2000) Physiological effects of extracellular nucleotides in the inner ear. Clin Exp Pharmacol Physiol 27:575-580.

Hudspeth AJ, Lewis RS (1988a) Kinetic analysis of voltage- and iondependent conductances in saccular hair cells of the bull-frog, Rana catesbeiana. J Physiol (Lond) 400:237-274.

Hudspeth AJ, Lewis RS (1988b) A model for electrical resonance and frequency tuning in saccular hair cells of the bull-frog, Rana catesbeiana. J Physiol (Lond) 400:275-297.

Kaufman MH (1992) The atlas of mouse development. San Diego: Academic.

Kharkovets T, Hardelin JP, Safieddine S, Schweizer M, El-Amraoui A, Petit C, Jentsch TJ (2000) KCNQ4, a K ${ }^{+}$channel mutated in a form of dominant deafness, is expressed in the inner ear and the central auditory pathway. Proc Natl Acad Sci USA 97:4333-4338.

Kros CJ, Ruppersberg JP, Rusch A (1998) Expression of a potassium current in inner hair cells during development of hearing in mice. Nature 394:281-284.

Kubisch C, Schroeder BC, Friedrich T, Lutjohann B, El-Amraoui A, Marlin S, Petit C, Jentsch TJ (1999) KCNQ4, a novel potassium channel expressed in sensory outer hair cells, is mutated in dominant deafness. Cell 96:437-446.

Lang DG, Correia MJ (1989) Studies of solitary semicircular canal hair cells in the adult pigeon. II. Voltage-dependent ionic conductances. J Neurophysiol 62:935-945.

Lawlor P, Marcotti W, Rivolta MN, Kros CJ, Holley MC (1999) Differentiation of mammalian vestibular hair cells from conditionally immortal, postnatal supporting cells. J Neurosci 19:9445-9458.

Marcotti W, Géléoc GS, Lennan GW, Kros CJ (1999) Transient expression of an inwardly rectifying potassium conductance in developing inner and outer hair cells along the mouse cochlea. Pflügers Arch 439:113-122.

Marcotti W, Johnson SL, Holley MC, Kros CJ (2003) Developmental changes in the expression of potassium currents of embryonic, neonatal and mature mouse inner hair cells. J Physiol (Lond) 548:383-400.

Masetto S, Correia MJ (1997) Electrophysiological properties of vestibular sensory and supporting cells in the labyrinth slice before and during regeneration. J Neurophysiol 78:1913-1927.

Masetto S, Russo G, Prigioni I (1994) Differential expression of potassium currents by hair cells in thin slices of frog crista ampullaris. J Neurophysiol 72:443-455.

Masetto S, Perin P, Malusa A, Zucca G, Valli P (2000) Membrane properties of chick semicircular canal hair cells in situ during embryonic development. J Neurophysiol 83:2740-2756.

Masetto S, Bosica M, Correia MJ, Ottersen OP, Zucca G, Perin P, Valli P (2003) $\mathrm{Na}^{+}$currents in vestibular type I and type II hair cells of the embryo and adult chicken. J Neurophysiol 90:1266-1278.

Mbiene JP, Favre D, Sans A (1984) The pattern of ciliary development in fetal mouse vestibular receptors. A qualitative and quantitative SEM study. Anat Embryol (Berl) 170:229-238.

Mbiene JP, Favre D, Sans A (1988) Early innervation and differentiation of hair cells in the vestibular epithelia of mouse embryos: SEM and TEM study. Anat Embryol (Berl) 177:331-340.

Navaratnam DS, Escobar L, Covarrubias M, Oberholtzer JC (1995) Permeation properties and differential expression across the auditory receptor epithelium of an inward rectifier $\mathrm{K}^{+}$channel cloned from the chick inner ear. J Biol Chem 270:19238-19245.

Neyroud N, Tesson F, Denjoy I, Leibovici M, Donger C, Barhanin J, Faure S, Gary F, Coumel P, Petit C, Schwartz K, Guicheney P (1997) A novel mutation in the potassium channel gene KVLQT1 causes the Jervell and Lange-Nielsen cardioauditory syndrome. Nat Genet 15:186-189.

Ohmori H (1984) Studies of ionic currents in the isolated vestibular hair cell of the chick. J Physiol (Lond) 350:561-581.

Oliver D, Plinkert P, Zenner HP, Ruppersberg JP (1997) Sodium current expression during postnatal development of rat outer hair cells. Pflügers Arch 434:772-778.

Platzer J, Engel J, Schrott-Fischer A, Stephan K, Bova S, Chen H, Zheng H, Striessnig J (2000) Congenital deafness and sinoatrial node dysfunction in mice lacking class D L-type $\mathrm{Ca}^{2+}$ channels. Cell 102:89-97.

Rennie KJ, Ashmore JF (1991) Ionic currents in isolated vestibular hair cells from the guinea-pig crista ampullaris. Hear Res 51:279-291.

Rennie KJ, Correia MJ (1994) Potassium currents in mammalian and avian isolated type I semicircular canal hair cells. J Neurophysiol 71:317-329.

Rennie KJ, Weng T, Correia MJ (2001) Effects of KCNQ channel blockers on $\mathrm{K}^{+}$currents in vestibular hair cells. Am J Physiol Cell Physiol 280:C473-C480.

Ricci AJ, Rennie KJ, Correia MJ (1996) The delayed rectifier, IKI, is the major conductance in type I vestibular hair cells across vestibular end organs. Pflügers Arch 432:34-42.

Ruben R (1967) Development of the inner ear of the mouse; a radioautographic study of terminal mitoses. Acta Otolaryngol [Suppl] 220:1-44.

Rüsch A, Eatock RA (1996) A delayed rectifier conductance in type I hair cells of the mouse utricle. J Neurophysiol 76:995-1004.

Rüsch A, Eatock RA (1997) Sodium currents in hair cells of the mouse utricule. In: Diversity in auditory mechanics (Lewis ER, Long GR, Lyon RF, Steele CR, Narins PM, Hecht-Poinar E, eds), pp 549-555. Singapore: World Scientific.

Rüsch A, Lysakowski A, Eatock RA (1998) Postnatal development of type I and type II hair cells in the mouse utricle: acquisition of voltage-gated conductances and differentiated morphology. J Neurosci 18:7487-7501.

Shatz CJ (1996) Emergence of order in visual system development. Proc Natl Acad Sci USA 93:602-608. 
Shou J, Zheng JL, Gao WQ (2003) Robust generation of new hair cells in the mature mammalian inner ear by adenoviral expression of Hath1. Mol Cell Neurosci 23:169-179.

Sokolowski BH, Stahl LM, Fuchs PA (1993) Morphological and physiological development of vestibular hair cells in the organ-cultured otocyst of the chick. Dev Biol 155:134-146.

Song H, Nie L, Rodriguez-Contreras A, Sheng ZH, Yamoah EN (2003) Functional interaction of auxiliary subunits and synaptic proteins with $\mathrm{Ca}_{\mathrm{v}} 1.3$ may impart hair cell $\mathrm{Ca}^{2+}$ current properties. J Neurophysiol 89:1143-1149.

Sugihara I, Furukawa T (1996) Inwardly rectifying currents in hair cells and supporting cells in the goldfish sacculus. J Physiol (Lond) 495:665-679.
Trussell L (2000) Mutant ion channel in cochlear hair cells causes deafness. Proc Natl Acad Sci USA 97:3786-3788.

Undrovinas AI, Maltsev VA, Kyle JW, Silverman N, Sabbah HN (2002) Gating of the late $\mathrm{Na}^{+}$channel in normal and failing human myocardium. J Mol Cell Cardiol 34:1477-1489.

Van De Water TR, Wersall J, Anniko M, Nordeman H (1978) Development of the sensory receptor cells in the utricular macula. Otolaryngol 86:297-304.

Watson CL, Gold MR (1997) Modulation of $\mathrm{Na}^{+}$current inactivation by stimulation of protein kinase C in cardiac cells. Circ Res 81:380-386.

Witt CM, Hu HY, Brownell WE, Bertrand D (1994) Physiologically silent sodium channels in mammalian outer hair cells. J Neurophysiol 72:1037-1040. 